\title{
DEVELOPMENT AND EVALUATION OF A SOLAR DRYER FOR THIN LAYER DRYING OF HAYANI DATE
} Matouk, A. M. ${ }^{1}$; M. M. El-Kholy ${ }^{2}$; M. A. El-Sadany' and A. E. Abd - El-aziz ${ }^{3}$

1- Agric. Eng. Dept., Fac. Agric., Mansoura Univ.

2- Agric. Eng. Res. Institute, ARC, Dokkie,Giza

3- Agric. Engineer

\begin{abstract}
A study was carried out to test and evaluate a forced convection solar dryer with auxiliary electric heater and temperature control system during thin layer drying of date . During the experimental work the temperature of drying air was adjusted to be approximately constant at $40,50,60$ and $70{ }^{\circ} \mathrm{C}$ and air velocity of $0.26,0.52$ and $0.78 \mathrm{~m} / \mathrm{min}$. High moisture hayani date was dried under three different treatments of date (peeled date, peeled treated date and unpeeled date ). Two empirical models (Exponential and Page) were examined to describe the drying behaviour and predict the change in moisture content of date during the drying process. Moisture content of date, thermal efficiency of the dryer and the total sugar and percentage reducing in sugars of the dried date were also determined. The obtained results showed that, both of the empirical models could satisfactorily be described the change in date moisture content during the drying process under specific conditions. On the other hand Page's model proved that it can predict and describe drying behaviour more adequately than the simple model. The dryer thermal efficiency increased with the increase of drying air temperature and air velocity and it ranged from 16.60 to $55.85 \%$.While the thermal efficiency of the solar collector ranged from $47.05 \%$ to $83.79 \%$. Also, the total and reducing sugars decreased with the decrease of drying air temperature and air velocity and it ranged from 40.33 to $44.66 \%$ d.b. for the reducing sugar and from 49.65 to $56.93 \%$ d.b. for the total soluable sugar.
\end{abstract}

\section{INTRODUCTION}

Date palm (Phoenix dactylifera L.) is one of the major fruit tree in Egypt. Date fruits are consumed in large quantities in Egypt. Date is eaten at all stages of the fruit development (khalal, rutub, and tamr). In addition to direct consumption, dates are processed in many ways, such as, date paste and date syrup( depis) (Mohamed and Ahmed, 1981).

Egypt is one of the countries, which has solar energy in abundance. It lies within the tropical and sub-tropical regions. It has a value of about 2.2 to $9.4 \mathrm{~kW}$ of solar energy per square meter per day, and sunshine duration per year extended from about 3000 to 4000 hours (Abdelatif, 1989).

In Egypt, natural sun drying is one of the common ways to conserve agricultural products. Considerable losses may occur during natural sun drying due to various influences, such as rodents, birds, insects, rain, storms and microorganisms .

Farmers harvest soft varieties of date before complete ripening stage or (rutab stage) and they are whether start marketing their product as fresh date in cheap price, or dry the product under sunshine (traditional methods) by 
spreading them on mats in the open air being directly exposed to solar radiation. This method is obviously not satisfactory as dust, dirt, rodents and insects can not be eliminated. On the other hands even this method has the advantage of non energy consumption, the total cost become high because of slow drying rate, long drying period and the need of large number of workers for frequent turning up the bed of date during the drying process and covering it during night time... etc.

Solar drying can be considered as an elaboration of sun drying and is an efficient system of utilizing solar energy (Bala, 1997a \& 1998, Zaman and Bala, 1989 and Muhlbauer, 1986). Several designs are available and these are (i) cabinet type solar drier suitable for drying fruits and vegetables (Sharma et.al, 1995), (ii) indirect natural convection solar drier for paddy drying (Oosthuizen, 1995) and mixed mode AIT drier for drying paddy(Excell, 1978).

The present study aims to design and test a forced convection solar dryer provided with auxiliary electric heater to provide and maintain the air drying temperature during drying high moisture date (Hayani var.) under different levels of drying air temperature, air velocity and date treatments. Two different drying models (simple exponential and Page) were examined for describing the drying behaviour of date. Thermal efficiency and final quality of the dried date were also determined.

Materials:

\section{MATERIALS AND METHODS}

The experimental work was executed at the department of Agricultural Engineering, Mansoura University during the period of September, October and November 2007 in Mansoura, Egypt

Fresh, ripe hand harvested samples of date palm (Hayani) were used in this study. It was obtained from a local date producing farm in Damitta governorate. The initial moisture content of the freshly harvested date was ranged from $97.36 \%$ to $118.45 \%$ dry basis and the total sugar content ranged from $44.58 \%$ to $65.14 \%$ dry basis.

Preparation of Samples:-

The date sample was divided into three sub samples as follows :

1 - The first sample was unpeeled only and coded as $\left(T_{1}\right)$.

2- The second sample was blanched by dipping in a solution containing $1.5 \%$

Potassium metabisulphite as recommended by Inayatullah et.al (1989) and coded as $\left(T_{2}\right)$.

3-The third sample was peeled date without any treatment and coded as $\left(T_{3}\right)$. Equipment

The solar dryer:-

A forced convection solar dryer shown in Fig (1) was constructed at a local workshop. The drying box of the dryer consists of four double sides of plywood that filled with an insulation (foam) of $5 \mathrm{~cm}$ thick. The gross dimensions of the box were $177,122,57.50$ and $107 \mathrm{~cm}$ for length, width , front height and back height respectively. The base of the drying box was made of a perforated stainless steel sheet to keep the dates from falling down 
and permit the air to move through it. A plenum chamber was formed under the drying box to allow air flow through the drying bed. The main solar collector was fixed at the front side of the dryer. The collector consists of a wooden frame of $266.5 \mathrm{~cm}$ long, $107.5 \mathrm{~cm}$ wide and $42 \mathrm{~cm}$ high surface area covered by $150 \mu$ thick plastic sheet. A corrugated black painted aluminium sheet was employed as an absorber plate and fixed at the center of the collector frame between the upper and bottom surfaces to increase the efficiency of energy collection and to allow the drying air to contact with both sides of the absorber plate. The slope of the collector was adjusted at $41^{\circ}$ with the horizontal level. While, the top surface of the dryer was covered by a plastic sheet of similar thickness. The dryer was carried out on four ground wheels of $0.75 \mathrm{~cm}$ diameter. An axial flow type fan was used for air suction through the drying bed at the required air flow rate .The components of the dryer and the direction of air flow are presented in Fig. (1). To maintain the drying air temperature constant at the required levels during the experimental work , $8 \mathrm{~kW}$ auxiliary electric heater with digital thermostat was also functioned .

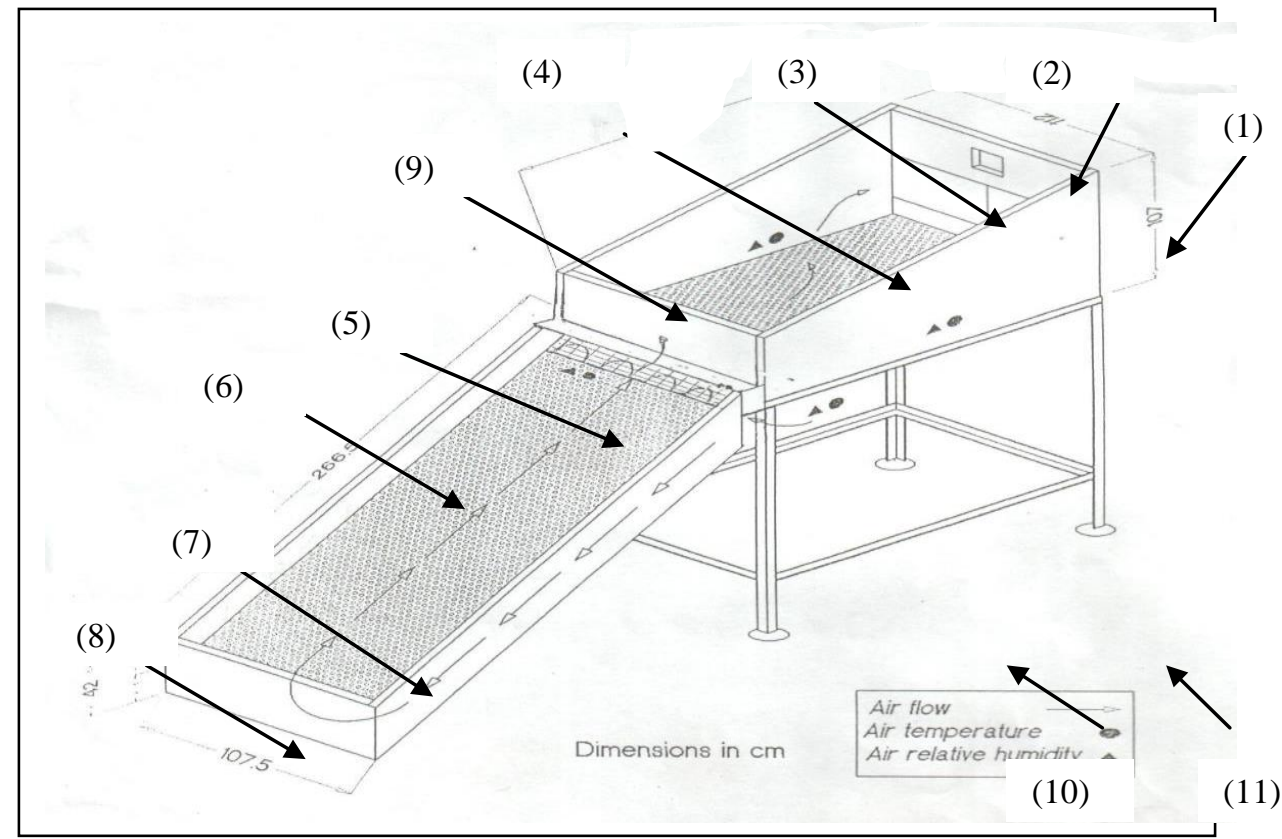

\begin{tabular}{|r|l|r|l|l|l|}
\hline 1 & The drying box & 2 & Air suction fan & 3 & $\begin{array}{l}\text { Charging and } \\
\text { discharging door }\end{array}$ \\
\hline 4 & Drying bed & 5 & Auxiliary heaters & 6 & The solar collector \\
\hline 7 & $\begin{array}{l}\text { Corrugated sheet of the } \\
\text { solar collector }\end{array}$ & 8 & Transparent cover & 9 & Transparent cover \\
\hline 10 & Dryer stands & 11 & \multicolumn{2}{|c}{ Ground caster wheels } \\
\hline
\end{tabular}

Fig.(1) : Schematic diagram of the developed solar dryer. 


\section{Experimental Measurements:}

\section{Date moisture content:}

The moisture content of date was determined by drying $10 \mathrm{~g}$ (in duplicate) samples of dates in an oven at $70^{\circ} \mathrm{C}$ until reached constant weight , according to (AOAC 1990).

\section{Air velocity and relative humidity:}

The velocity of drying air was measured using a digital air velocity instrument connected with a velocity probe 0.1 to $10 \mathrm{~m} / \mathrm{sec}$ and accuracy of \pm $0.1 \mathrm{~m} / \mathrm{s}$.

\section{Air temperature :}

A digital thermometer of 12 points -40 to $104.4 \stackrel{\circ}{\circ} \mathrm{C}$ and accuracy of \pm 0.2 ㄷ $\mathrm{C}$ was used for measuring the air and date bulk temperatures at different points inside and outside the dryer. The air relative humidity was also measured at the same points using a humidity meter mode (H.D-205).

\section{Solar radiation.}

The solar radiation data were collected from weather station installed on the roof of Agriculture Engineering Department, Mansoura University.

\section{The overall thermal efficiency of the solar dryer}

The ratio of useful heat $\left(Q_{u}\right)$ to the available heat $\left(Q_{i}\right)$ is defined as the efficiency of solar drying system $\left(\eta_{\text {th }}\right)$. It can be calculated as follows (Abdelatif, 1989):

$$
\begin{array}{ll}
\eta_{\text {th }}=\left(Q_{U} / Q_{I}\right) \times 100 & , \% \\
Q_{U}=m_{r} h_{\text {gg }} / 3600 & , k W \\
Q_{I}=A_{C} R+Q_{E} & , k W
\end{array}
$$

Where:

$\mathrm{m}_{\mathrm{r}}=$ mass of moisture removed, $\mathrm{kg} / \mathrm{hr}$.

$\mathrm{h}_{\mathrm{fg}}=$ Latent heat of vaporization of water, $\mathrm{kJ} / \mathrm{kg}$.

$A_{c}=$ area of collector, $\mathrm{m}^{2}$.

$\mathrm{R}=$ solar radiation flux incident, $\mathrm{W} / \mathrm{m}^{2}$.

$Q_{E}=$ electric energy of heaters,$W$.

The latent heat of vaporization of water was taken from steam table as $2406.8,2382.8,2358.5$ and $2333.8 \mathrm{~kJ} / \mathrm{kg}$ at drying air temperature of 40,50 , 60 and $70{ }^{\circ} \mathrm{C}$, respectively .

\section{Total sugar and percentage reduction in sugars:}

Total sugar and percentage reduction in sugars were extracted by ethanol $80 \%$ and determined according to the method descriped by Somogi (1952).

\section{Experimental procedure:}

Before each run, the dryer was adjusted at the required level of drying air temperature and air velocity. After that, the dryer bed was loaded with the date sample which was distributed uniformly in a single layer. Air velocity and relative humidity were measured every hour during the drying process . While the moisture content of date was determined throughout the drying period at different time intervals and different places of the drying bed until the moisture content almost ceased to approach the final moisture content.

Two different drying models (simple exponential and Page) were examined for describing the thin layer drying behaviour of date palm . 
The final moisture content $\left(\mathrm{M}_{\mathrm{f}}\right)$ was used as an approximate value for the dynamic equilibrium moisture content, taking into account that the drying runs were turned off when the reduction in moisture content was almost ceased, as previously mentioned by Matouk et al. (2002) and El-Sahrigi et al. (2006). The two models are presented as follows:

1-The simple exponential model:

$$
M R=\frac{M-M_{f}}{M_{o}-M_{f}}=\exp \left(-k_{s} t\right)
$$

1- Page model

$$
M R=\frac{M-M_{\mathrm{f}}}{M_{o}-M_{\mathrm{f}}}=\exp \left(-k_{p} t^{u}\right)
$$

Where:

MR : Moisture ratio, dimensionless

$\mathrm{M}$ : Average moisture content at time t, (d.b) $\mathrm{kg}$ water / $\mathrm{kg}$ dry solid.

$M_{f}$ : Final moisture content. (d.b) $\mathrm{kg}$ water / kg dry solid.

$\mathrm{t} \quad$ : Time, $\min$

$\mathrm{k}_{\mathrm{s}, \mathrm{p}}$ : Drying constants, $\min ^{-1}$

$\mathrm{u}$ : Experimental constant, dimensionless follows:

To calculate the drying constants, the two models were linearized as

1-The simple exponential model:

$$
\operatorname{LnMR}=-k_{s} t
$$

2-The Page model:

$$
\operatorname{Ln}(-\operatorname{LnMR})=\operatorname{Ln}\left(k_{p}\right)+u \cdot \operatorname{Ln}(t)
$$

The drying constant $\left(\mathrm{k}_{\mathrm{s}}\right)$ of the simple exponential model was obtained by applying linear regression analysis to the values $L n(M R)$ and the elapsed drying time (t) (Eq. 3). The slope of the best fit straight line represents the drying constant $\left(\mathrm{k}_{\mathrm{s}}\right)$.

On the other hand the values of the drying constants of Peg's model ( $k_{p}$ and $\mathrm{u}$ ), were obtained by applying linear regression analysis to the values of Ln [-Ln (MR )] and the corresponding drying time (Eq. 4). The slope of the fitted line represents the constant $(u)$ while the value of the anti log of the intercept represents the constant $\left(k_{p}\right)$.

\section{Solar radiation:}

\section{RESULTS AND DISCUSSION}

To study the thermal performance of the solar dryer it was imperative to consider the amount of solar radiation during the drying process .The hourly average solar radiation flux incident on a horizontal surface during the period of September, October and November 2007 in Mansoura, Egypt were $672.13,469.33$ and $315.19 \mathrm{~W} / \mathrm{m}^{2}$ for September, October and November, respectively. Fig (2) shows the measured solar energy flux incident during the experimental work .In general, the solar radiation gradually increased from 
sunrise till it reached the maximum value at noon, it then decreased gradually until it reached the minimum value at sunset. The observed variation in solar energy available during the drying period affected the dryer effectiveness in heating air and the differences in air temperature and relative humidity between the inside and outside the solar collector.
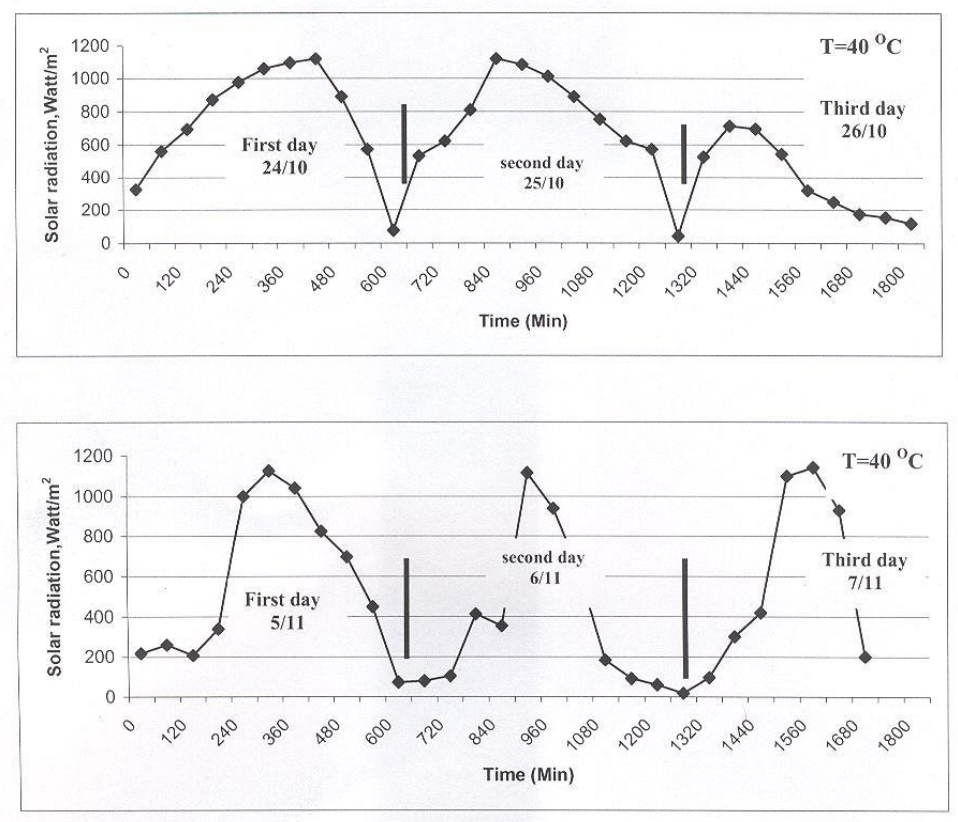

Fig. (2): Solar radiation flux incident versus drying time .

\section{Date Moisture Content:}

Figure (3) shows the change in date moisture content as related to drying time for different date treatments. It can be seen that the rate of moisture reduction increased with the increase of air temperature and air velocity and it was higher for the unpeeled date (T1) followed by the un-peeled treated date (T2) and the peeled untreated date (T3), respectively . 
J. Soil Sci. and Agric. Engineering, Mansoura Univ., Vol.1 (6), June, 2010

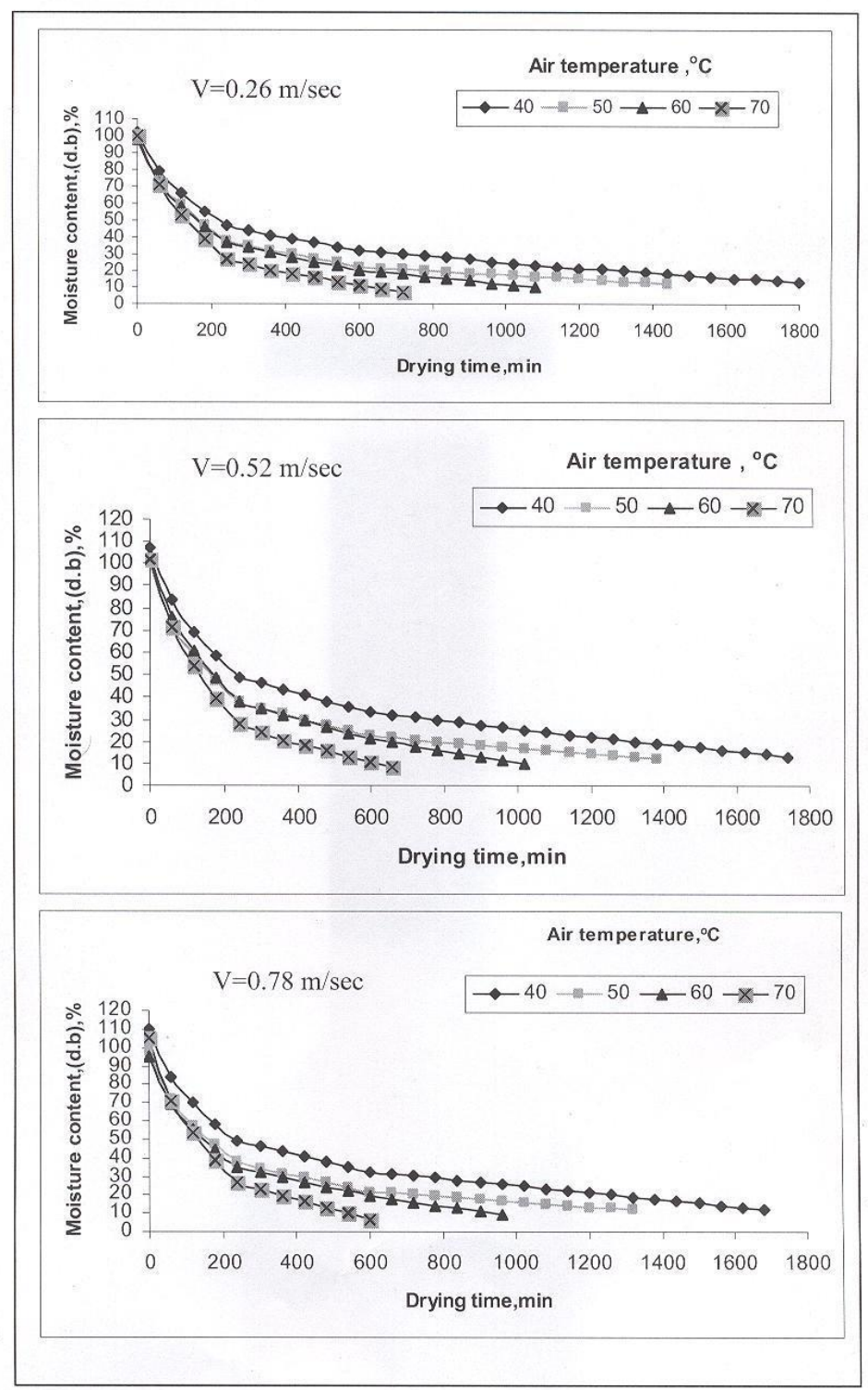

Fig.( 3): Change in moisture content of peeled date as related to drying time at different air temperatures and air velocities.

The results of the drying process are summarized and listed in table (1). It indicates that the lowest values of final moisture content occurred with the peeled date treatment followed by the unpeeled treated date and the unpeeled untreated date, respectively. 
Matouk, A. M. et al.

Table 1: Value of drying constants $\left(k_{s}, k_{p}, u\right)$ at different studied drying parameters determined at the average values of final and equilibrium moisture content $\left(\mathrm{M}_{\mathrm{f}}\right.$ and $\left.\mathrm{M}_{\mathrm{e}}\right)$.

\begin{tabular}{|c|c|c|c|c|c|c|c|c|c|c|}
\hline $\begin{array}{c}\text { Date } \\
\text { conditions }\end{array}$ & $\begin{array}{l}\mathrm{V} \\
\mathrm{m} / \mathrm{s}\end{array}$ & $\begin{array}{l}\mathrm{T}, \\
{ }^{\circ} \mathrm{C}\end{array}$ & $\begin{array}{l}\mathbf{M}_{\mathrm{f}} \\
\text { \%d.b }\end{array}$ & $\begin{array}{l}M_{e}, \\
\% d . b\end{array}$ & $\begin{array}{c}\mathbf{k}_{\mathrm{s}} \\
\text { at } \mathbf{m}_{\mathrm{f}}, \\
\% \mathrm{~d} . \mathbf{b}\end{array}$ & $\begin{array}{c}\mathbf{k}_{\mathbf{s}} \\
\text { at } \mathbf{m}_{\mathrm{e}}, \\
\% \text { d.b }\end{array}$ & $\begin{array}{c}k_{p} \\
\text { at } \mathbf{m}_{\mathrm{f}}, \\
\% \mathrm{~d} \cdot \mathbf{b}\end{array}$ & $\begin{array}{c}\mathbf{k}_{\mathrm{p}} \\
\text { at } \mathbf{m}_{\mathrm{e}}, \\
\% \text { d.b }\end{array}$ & $\begin{array}{c}\mathbf{u} \\
\text { at } \mathbf{m}_{\mathrm{f}}, \\
\% \mathrm{~d} . \mathrm{b}\end{array}$ & $\begin{array}{c}\mathrm{u} \\
\text { at } \mathrm{m}_{\mathrm{e}}, \\
\% \mathrm{~d} . \mathrm{b}\end{array}$ \\
\hline \multirow{12}{*}{$\begin{array}{l}\text { Unpeeled } \\
\text { date } \\
\left(\mathrm{T}_{1}\right)\end{array}$} & \multirow{4}{*}{1} & 40 & 13.86 & 13.16 & 0.0041 & 0.0039 & 0.012 & 0.0103 & 0.772 & 0.7336 \\
\hline & & 50 & 12.73 & 12.24 & 0.0065 & 0.0062 & 0.0232 & 0.0244 & 0.8173 & 0.8003 \\
\hline & & 60 & 10.98 & 10.36 & 0.0098 & 0.0088 & 0.0315 & 0.034 & 0.8427 & 0.8642 \\
\hline & & 70 & 9.32 & 8.47 & 0.0118 & 0.0108 & 0.039459 & 0.0427 & 0.9134 & 0.8866 \\
\hline & \multirow{4}{*}{1.5} & 40 & 13.57 & 12.66 & 0.0046 & 0.0042 & 0.0154 & 0.0155 & 0.7539 & 0.7238 \\
\hline & & 50 & 12.29 & 11.7 & 0.0079 & 0.0075 & 0.026 & 0.03 & 0.7844 & 0.7702 \\
\hline & & 60 & 10.34 & 10.04 & 0.01 & 0.0095 & 0.035501 & 0.0394 & 0.8242 & 0.8045 \\
\hline & & 70 & 8.42 & 8.23 & 0.0131 & 0.0125 & 0.0433 & 0.0484 & 0.8954 & 0.8694 \\
\hline & \multirow{4}{*}{2} & 40 & 13.12 & 12.2 & 0.0049 & 0.0045 & 0.0197 & 0.02 & 0.7486 & 0.6764 \\
\hline & & 50 & 11.84 & 11.14 & 0.0083 & 0.0076 & 0.0323 & 0.0347 & 0.772 & 0.7619 \\
\hline & & 60 & 10.00 & 9.57 & 0.0107 & 0.0098 & 0.0413 & 0.0445 & 0.803 & 0.7905 \\
\hline & & 70 & 7.89 & 7.71 & 0.0135 & 0.0131 & 0.046911 & 0.054 & 0.8648 & 0.8476 \\
\hline \multirow{12}{*}{$\begin{array}{l}\text { Unpeeled } \\
\text { treated } \\
\text { date } \\
\left(\mathrm{T}_{2}\right)\end{array}$} & \multirow{4}{*}{1} & 40 & 13.65 & 12.53 & 0.0058 & 0.0046 & 0.0122 & 0.010445 & 0.76 & 0.7247 \\
\hline & & 50 & 12 & 11.41 & 0.0067 & 0.0063 & 0.024 & 0.0247 & 0.787 & 0.777 \\
\hline & & 60 & 10 & 9.90 & 0.0099 & 0.009 & 0.0326 & 0.0353 & 0.8247 & 0.82 \\
\hline & & 70 & 8.26 & 7.55 & 0.0133 & 0.012 & 0.040798 & 0.044 & 0.9004 & 0.8709 \\
\hline & \multirow{4}{*}{1.5} & 40 & 12.88 & 11.77 & 0.0065 & 0.0059 & 0.0155 & 0.0164 & 0.735 & 0.692 \\
\hline & & 50 & 11.37 & 10.67 & 0.0083 & 0.0076 & 0.0293 & 0.0312 & 0.7673 & 0.74 \\
\hline & & 60 & 9.45 & 9.03 & 0.0106 & 0.0097 & 0.0363 & 0.0405 & 0.8223 & 0.7825 \\
\hline & & 70 & 8.02 & 7.11 & 0.0143 & 0.0142 & 0.0449 & 0.0488 & 0.8883 & 0.8534 \\
\hline & \multirow{4}{*}{2} & 40 & 12.34 & 11.30 & 0.0069 & 0.0059 & 0.02 & 0.026384 & 0.704 & 0.6747 \\
\hline & & 50 & 10.83 & 10 & 0.0089 & 0.0077 & 0.0349 & 0.039097 & 0.735 & 0.7249 \\
\hline & & 60 & 9.04 & 8.25 & 0.0108 & 0.0099 & 0.041382 & 0.046715 & 0.7788 & 0.7675 \\
\hline & & 70 & 7.66 & 6.59 & 0.015 & 0.0149 & 0.050813 & 0.056 & 0.8583 & 0.8422 \\
\hline \multirow{12}{*}{$\begin{array}{c}\text { Peeled } \\
\text { date } \\
\left(\mathrm{T}_{3}\right)\end{array}$} & \multirow{4}{*}{1} & 40 & 12.6 & 12.17 & 0.0063 & 0.0051 & 0.016 & 0.02 & 0.7535 & 0.7227 \\
\hline & & 50 & 11.05 & 10.8 & 0.0077 & 0.0069 & 0.02253 & 0.0307 & 0.7897 & 0.7444 \\
\hline & & 60 & 9.63 & 8.68 & 0.0101 & 0.0098 & 0.0333 & 0.0405 & 0.84 & 0.7865 \\
\hline & & 70 & 8.03 & 6.28 & 0.0153 & 0.0129 & 0.041974 & 0.0507 & 0.891 & 0.8496 \\
\hline & \multirow{4}{*}{1.5} & 40 & 11.85 & 11.59 & 0.0069 & 0.0062 & 0.022 & 0.0256 & 0.7139 & 0.7012 \\
\hline & & 50 & 11.52 & 10 & 0.0087 & 0.0081 & 0.0295 & 0.034 & 0.76 & 0.7377 \\
\hline & & 60 & 9.02 & 7.98 & 0.0108 & 0.01 & 0.038704 & 0.0428 & 0.813 & 0.7758 \\
\hline & & 70 & 6.42 & 5.87 & 0.0159 & 0.015 & 0.046491 & 0.054 & 0.8661 & 0.8414 \\
\hline & & 40 & 11.07 & 10.66 & 0.0071 & 0.0068 & 0.0277 & 0.0307 & 0.6937 & 0.675 \\
\hline & & 50 & 9.5 & 9.15 & 0.0091 & 0.0085 & 0.0352 & 0.0391 & 0.727 & 0.722 \\
\hline & & 60 & 8.00 & 7.4 & 0.0113 & 0.0102 & 0.044073 & 0.0484 & 0.7842 & 0.7744 \\
\hline & & 70 & 6.84 & 5.05 & 0.0178 & 0.0158 & 0.0509 & 0.0567 & 0.8566 & 0.8241 \\
\hline
\end{tabular}

To determine the interaction effect of drying air temperature and air velocity on the final moisture content of different date treatment a multiple regression analysis was used. The nature of dependence can be described by the empirical relation as follows :

$$
\mathrm{M}_{\mathrm{f}}=\mathrm{a}-\mathrm{b}(\mathrm{V})-\mathrm{c}(\mathrm{T})
$$

Where:

$M_{f}=$ the final moisture content, $\%(d . b)$

$\mathrm{a}, \mathrm{b}, \mathrm{c}=$ constants

$\mathrm{T}=$ drying air temperature, ${ }^{\circ} \mathrm{C}$

$\mathrm{V}=$ drying air velocity, $\mathrm{m} / \mathrm{s}$ 
Table (2) reveals the data of the multiple regression analysis. It shows that, the final moisture content $\left(\mathrm{M}_{\mathrm{f}}\right)$ was strongly affected by the drying air temperature and air velocity for all date treatments.

Table (2): Constants of equations (11) relating the final moisture content with the drying parameters.

\begin{tabular}{|c|c|c|c|c|c|}
\hline \multirow{2}{*}{ Date conditions } & \multicolumn{5}{|c|}{ Final moisture content (Mf) \% (d. b.) } \\
\cline { 2 - 6 } & $\mathbf{a}$ & $\mathbf{b}$ & $\mathbf{C}$ & $\left(\mathbf{R}^{\mathrm{\alpha}}\right)$ & $\mathbf{S E}$ \\
\hline $\mathrm{T}_{1}$ & 21.93383 & -3.23558 & -0.14727 & 0.93 & 0.548305 \\
\hline $\mathrm{T}_{2}$ & 21.45217 & -2.44712 & -0.1631 & 0.97 & 0.349311 \\
\hline $\mathrm{T}_{3}$ & 19.90317 & -2.73558 & -0.15797 & 0.98 & 0.269075 \\
\hline
\end{tabular}

\section{Drying Constants $\mathbf{k}_{\mathbf{s}}, \mathrm{k}_{\mathrm{p}}$ and $\mathrm{u}$ :}

The two drying models were applied to the data and the drying constants for both models are presented in table (1). In section of the data tabulated in table (1) showed that drying constants of both drying models were affected by the drying parameters (air temperature and air velocity).

A multiple regression analysis was employed to study the effect of both air temperature and air velocity on the drying constants $\mathrm{k}_{\mathrm{s}}$ of the simple exponential equation and the drying constants $k_{p}$ and $u$ of the Page equation The nature of dependence could be described by empirical relations as follow :

$$
\begin{aligned}
k s & =d+e(T)+f(V) \\
k p & =g+h(T)+k(V) \\
u & =l+m(T)+n(V)
\end{aligned}
$$

The constants of equations (12,13 and 14 ) are presented in table (3). Also Fig . (4) illustrates the drying constants $k_{s}, k_{p}$ and $u$ as related to drying air temperature and velocity for the peeled date treatment $\left(T_{3}\right)$. It must be mentioned that the same trend of relation was also noticed with the other two treatments. In general the drying constants $k_{s}$, $k_{p}$ increased with the increase of drying air temperature and air velocity. While the constant $u$ increased with the drying air temperature and decreased with the increase of air velocity. These results are in agreement with that obtained by Pangavhane, et al. (1999) and Azzouz, et al. (2002).

Table (3): Constants of equations (8,9 and 10) for different date treatments.

\begin{tabular}{|c|l|c|c|c|c|c|}
\hline Drying constant & Date treatment & $\mathbf{d}$ & $\mathbf{e}$ & $\mathbf{f}$ & $\mathbf{R}^{2}$ & $\mathbf{S E}$ \\
\hline \multirow{3}{*}{$\mathrm{k}_{\mathrm{s}}$} & $\mathrm{T} 1$ & -0.00164 & 0.002173 & 0.0000646 & 0.90 & 0.000324 \\
\cline { 2 - 7 } & $\mathrm{T} 2$ & -0.00261 & 0.002245 & 0.0000937 & 0.97 & 0.000249 \\
\cline { 2 - 7 } & $\mathrm{T} 3$ & -0.00289 & 0.001813 & 0.000106 & 0.97 & 0.000239 \\
\hline \multirow{4}{*}{$\mathrm{k}_{\mathrm{p}}$} & Date treatment & $\mathrm{g}$ & $\mathrm{h}$ & $\mathrm{k}$ & $\mathrm{R}^{2}$ & $\mathrm{SE}$ \\
\cline { 2 - 7 } & $\mathrm{T} 1$ & 0.002091 & 0.006135 & 0.000754 & 0.98 & 0.000277 \\
\cline { 2 - 7 } & $\mathrm{T} 2$ & 0.000942 & 0.008618 & 0.0000896 & 0.99 & 0.000286 \\
\cline { 2 - 7 } & T3 & 0.00033 & 0.010243 & 0.000111 & 0.96 & 0.000585 \\
\hline \multirow{4}{*}{$\mathrm{u}$} & Date treatment & $\mathrm{I}$ & $\mathrm{m}$ & $\mathrm{n}$ & $\mathrm{R}^{2}$ & $\mathrm{SE}$ \\
\cline { 2 - 7 } & $\mathrm{T} 1$ & 0.731281 & -0.19027 & 0.001684 & 0.99 & 0.005068 \\
\cline { 2 - 7 } & $\mathrm{T} 2$ & 0.742831 & -0.18673 & 0.001558 & 0.99 & 0.004851 \\
\cline { 2 - 7 } & T3 & 0.77163 & -0.28865 & 0.001912 & 0.99 & 0.003865 \\
\hline
\end{tabular}


Matouk, A. M. et al.
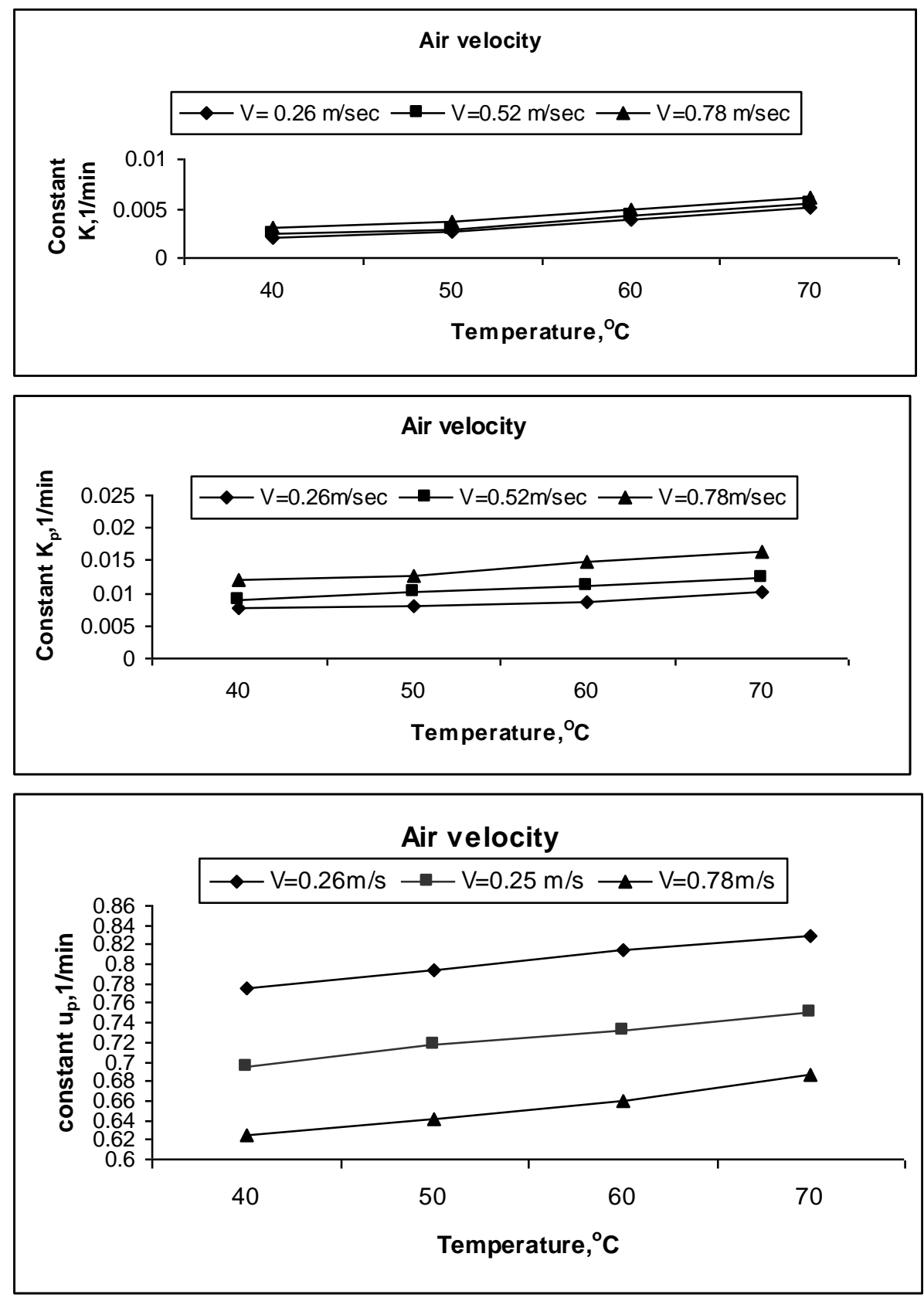

Fig.( 4): Drying constants ( $k_{s}, k_{p}$ and $u$ ) as related to drying temperature at different air velocities for the peeled date $\left(T_{3}\right)$. 
Evaluation of the models:

The moisture content of date at any time during the drying process could be estimated using the previous expressions with more accuracy. The consistency of the models and relationship between the coefficients and drying variables was evident with the high values of $R^{2}$ and SE shown in Table (3). Fig. (5) indicates the comparison of the predicted and the experimental moisture content (for both model at highest temperature level) for both drying models. Both models (Simple and Page) provided satisfactorily a good conformity between experimental and predicted moisture content, and predicted data generally banded around the straight line, which showed the suitability of the models in describing solar drying behaviour of date. Values of the coefficient of determination and standard error as estimated for all straight lines which are used to compare predicted and experimental moisture contents are shown in table (4). Moreover, the results showed that, both the simple exponential and the Page drying models could satisfactory describe the drying behaviour of date under the tested ranges of experimental treatments. While, the Page's model was more appropriate for describing the drying behaviour of date and predicting the change in date moisture content during the drying process Similar pattern was also noticed for the other runs.

Table (4): Values of regression coefficient $\left(R^{2}\right)$ and standard error (SE) for both forms of simple and Page drying equations.

\begin{tabular}{|c|c|c|c|c|c|c|c|}
\hline \multirow{4}{*}{ 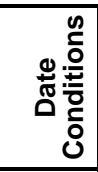 } & \multirow{4}{*}{ 竞 } & \multicolumn{6}{|c|}{ Simple exponential model } \\
\hline & & \multicolumn{6}{|c|}{ Air velocity, $\mathrm{m} / \mathrm{s}$} \\
\hline & & \multicolumn{2}{|c|}{0.26} & \multicolumn{2}{|c|}{0.52} & \multicolumn{2}{|c|}{0.78} \\
\hline & & SE & $\mathbf{R}^{\mathbf{2}}$ & SE & $\mathbf{R}^{2}$ & SE & $\mathbf{R}^{2}$ \\
\hline \multirow{4}{*}{ T1 } & 40 & 6.518 & 0.95 & 6.881 & 0.94 & 7.485 & 0.94 \\
\hline & 50 & 6.830 & 0.95 & 4.205 & 0.98 & 6.239 & 0.95 \\
\hline & 60 & 5.03 & 0.96 & 3.657 & 0.98 & 3.893 & 0.97 \\
\hline & 70 & 3.416 & 0.99 & 7.857 & 0.93 & 2.499 & 0.99 \\
\hline \multirow{4}{*}{ T2 } & 40 & 8.163 & 0.94 & 8.014 & 0.94 & 3.814 & 0.98 \\
\hline & 50 & 2.702 & 0.99 & 4.013 & 0.98 & 5.908 & 0.96 \\
\hline & 60 & 4.09 & 0.98 & 3.968 & 0.98 & 8.078 & 0.91 \\
\hline & 70 & 4.64 & 0.96 & 6.801 & 0.94 & 2.535 & 0.99 \\
\hline \multirow{4}{*}{ T3 } & 40 & 6.23 & 0.96 & 7.510 & 0.94 & 8.25 & 0.94 \\
\hline & 50 & 2.67 & 0.99 & 3.885 & 0.98 & 5.9176 & 0.95 \\
\hline & 60 & 4.67 & 0.97 & 3.689 & 0.98 & 4.120 & 0.98 \\
\hline & 70 & 3.45 & 0.99 & 6.934 & 0.94 & 8.011 & 0.92 \\
\hline \multirow{4}{*}{ 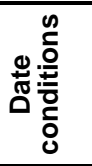 } & \multirow{4}{*}{ 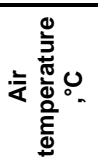 } & \multicolumn{6}{|c|}{ Page model } \\
\hline & & \multicolumn{6}{|c|}{ Air velocity, $\mathrm{m} / \mathrm{s}$} \\
\hline & & \multicolumn{2}{|c|}{0.26} & \multicolumn{2}{|c|}{0.52} & \multicolumn{2}{|c|}{0.78} \\
\hline & & SE & $\mathbf{R}^{2}$ & SE & $\mathbf{R}^{2}$ & SE & $\mathbf{R}^{2}$ \\
\hline \multirow{4}{*}{$\mathrm{T} 1$} & 40 & 0.0102152 & 0.99 & $1.9 \mathrm{E}-06$ & 1 & $1.98 \mathrm{E}-06$ & 1 \\
\hline & 50 & $3.42 \mathrm{E}-07$ & 1 & $1.527 \mathrm{E}-08$ & 1 & $1.95 \mathrm{E}-07$ & 1 \\
\hline & 60 & $7.83 E-08$ & 1 & $1.66 \mathrm{E}-11$ & 1 & $7.7 \mathrm{E}-12$ & 1 \\
\hline & 70 & $1.612 \mathrm{E}-09$ & 1 & $8.025 \mathrm{E}-14$ & 1 & $5.88 \mathrm{E}-10$ & 1 \\
\hline \multirow{4}{*}{ T2 } & 40 & 0.053749 & 0.99 & $2.11 \mathrm{E}-06$ & 1 & $1.45 \mathrm{E}-08$ & 1 \\
\hline & 50 & $1.27 \mathrm{E}-07$ & 1 & $1.9 \mathrm{E}-08$ & 1 & $1.84 \mathrm{E}-07$ & 1 \\
\hline & 60 & $2.1 \mathrm{E}-09$ & 1 & $1.55 \mathrm{E}-11$ & 1 & 0.0255 & 0.99 \\
\hline & 70 & 1.67E-09 & 1 & $2.37 \mathrm{E}-15$ & 1 & $1.23 \mathrm{E}-10$ & 1 \\
\hline \multirow{4}{*}{ T3 } & 40 & $9.83 \mathrm{E}-07$ & 1 & $1.99 \mathrm{E}-06$ & 1 & $2.18 \mathrm{E}-06$ & 1 \\
\hline & 50 & $6.31 \mathrm{E}-10$ & 1 & $1.63 \mathrm{E}-08$ & 1 & $1.85 \mathrm{E}-07$ & 1 \\
\hline & 60 & $1.69 \mathrm{E}-08$ & 1 & $1.55 \mathrm{E}-11$ & 1 & $1.13 \mathrm{E}-08$ & 1 \\
\hline & 70 & $1.629 \mathrm{E}-09$ & 1 & $2.368 \mathrm{E}-15$ & 1 & $1.27 \mathrm{E}-11$ & 1 \\
\hline
\end{tabular}



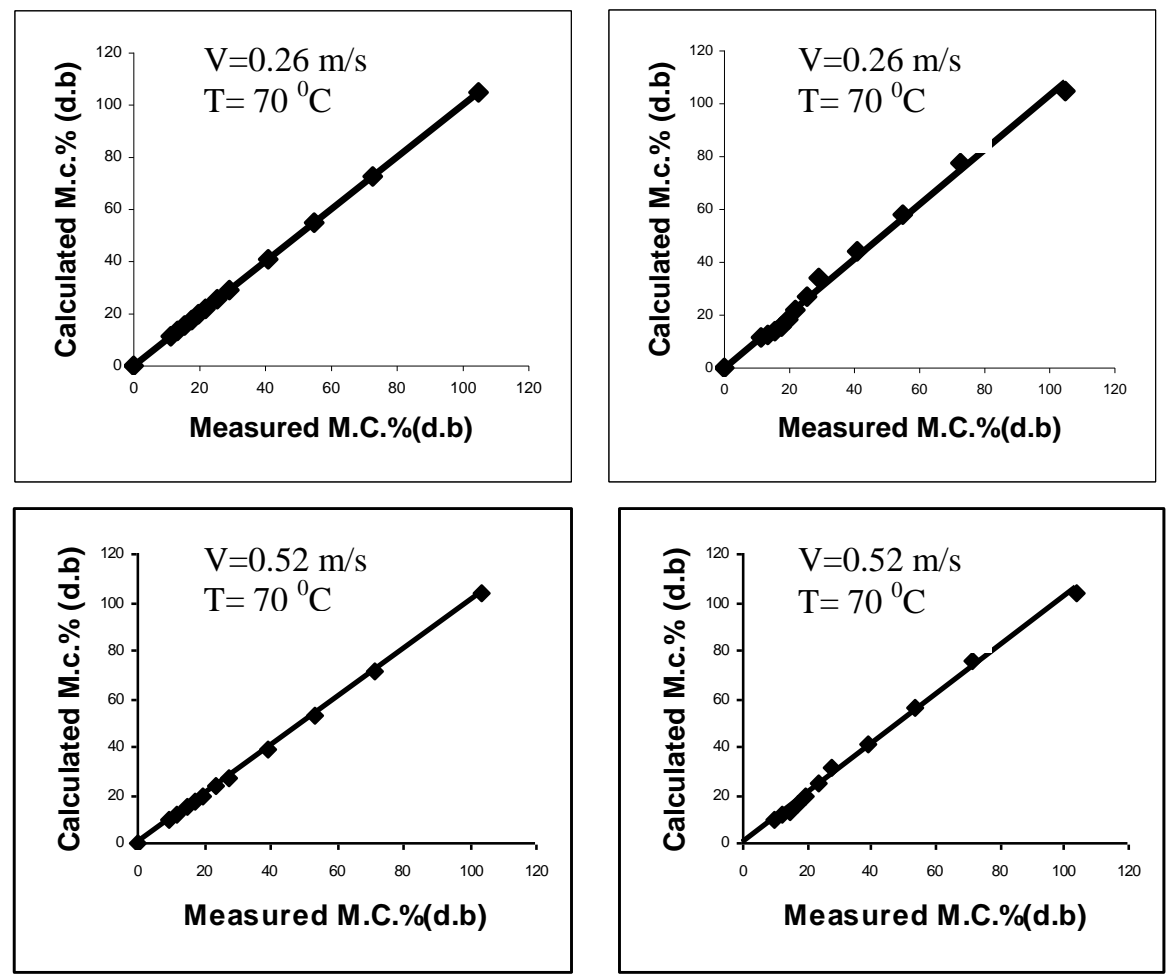

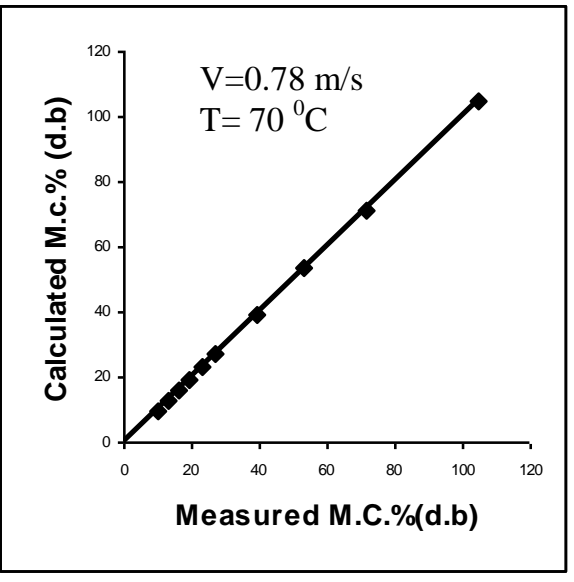

(a) Simple model

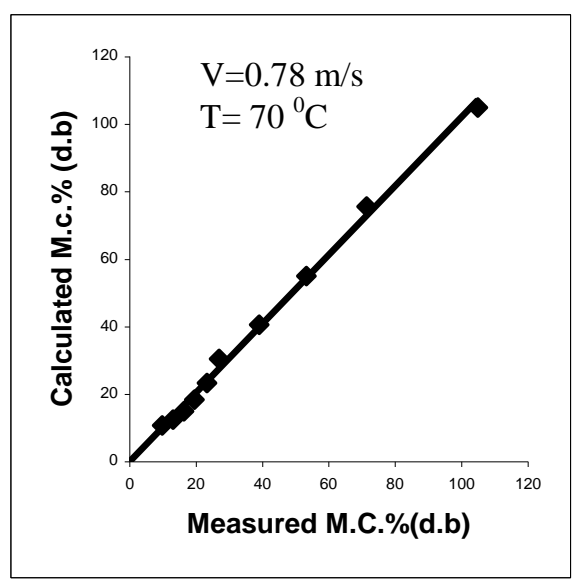

(b) Page's model

Fig. (5): Measured and calculated values of moisture content for the peeled date treatment for both models at the highest air temperature. 
Total and reducing Sugars:

Total and reducing Sugars decreased with the decrease of the drying air temperature and air velocity. As shown in table (5) at the minimum drying air temperature of $40{ }^{\circ} \mathrm{C}$ and air velocity of $0.26 \mathrm{~m} / \mathrm{sec}$, the average total sugars for $\left(T_{1}, T_{2}\right.$ and $\left.T_{3}\right)$ was $49.65,49.85$ and $49.96 \%$ (d.b) and the average reducing in sugar was $40.33,40.55$ and $40.61 \%$ (d.b) respectively. While at the maximum drying air temperature of $70{ }^{\circ} \mathrm{C}$ and air velocity of $0.78 \mathrm{~m} / \mathrm{sec}$ the total sugar was $56.49,56.75$ and $56.93 \%$ (d.b) and the average reduction sugar was $44.76,44.52$ and $44.66 \%$ (d.b), respectively. This observation may be attributed to the liberation of sugars from soluble tannins and other compounds such as hemicelluloses as reported by Kamal (1968). Also the long time of heating led to decrease the reducing sugars during the drying process due to the browning reaction as mentioned by (Reynolds, 1965).

Table (5): Total and reducing soluble sugars \% (d.b) of the dried date.

\begin{tabular}{|c|c|c|c|c|c|c|c|}
\hline $\begin{array}{c}\text { Air velocity } \\
\text { m/sec }\end{array}$ & \multirow{2}{*}{ Temperature, ${ }^{\mathbf{0}} \mathbf{C}$} & \multicolumn{2}{|c|}{ Reducing sugars, \%(d.b) } & \multicolumn{3}{|c|}{ Total soluble sugars,\% (d.b) } \\
\cline { 2 - 8 } & & $\mathbf{T}_{1}$ & $\mathbf{T}_{2}$ & $\mathbf{T}_{3}$ & $\mathbf{T}_{1}$ & $\mathbf{T}_{2}$ & $\mathbf{T}_{3}$ \\
\hline \multirow{4}{*}{0.26} & 40 & 40.33 & 40.55 & 40.61 & 49.65 & 49.85 & 49.96 \\
\cline { 2 - 8 } & 50 & 41.44 & 41.66 & 41.72 & 51.48 & 51.68 & 51.79 \\
\cline { 2 - 8 } & 60 & 42.59 & 43.1 & 42.97 & 53.16 & 53.57 & 53.75 \\
\cline { 2 - 8 } & 70 & 43.65 & 43.86 & 43.95 & 54.98 & 55.19 & 55.28 \\
\hline \multirow{4}{*}{0.52} & 40 & 40.75 & 41.02 & 40.88 & 50.19 & 50.38 & 50.57 \\
\cline { 2 - 8 } & 50 & 41.66 & 41.88 & 42.03 & 51.68 & 51.95 & 52.2 \\
\cline { 2 - 8 } & 60 & 42.83 & 42.77 & 43.35 & 53.88 & 54.09 & 54.71 \\
\cline { 2 - 8 } & 70 & 44.26 & 44.11 & 44.35 & 55.68 & 55.93 & 56.17 \\
\hline \multirow{4}{*}{0.78} & 40 & 41.05 & 41.12 & 41.27 & 50.85 & 50.92 & 51.29 \\
\cline { 2 - 8 } & 50 & 42.41 & 42.33 & 42.19 & 52.91 & 52.63 & 52.79 \\
\cline { 2 - 8 } & 60 & 43.49 & 43.41 & 43.86 & 54.42 & 54.59 & 55.19 \\
\cline { 2 - 8 } & 70 & 44.76 & 44.52 & 44.66 & 56.49 & 56.75 & 56.93 \\
\hline
\end{tabular}

Thermal efficiency of the solar collector and the dryer :

Table (6) shows the overall thermal efficiency of the solar dryer with the auxiliary electric heater for the drying process. The overall thermal efficiency of the dryer ranged from $29.29 \%$ to $36.87 \%$.It indicates that the solar collector provided $31.03 \%, 28.80 \%, 21 \%$ and $11.19 \%$ of the total heat energy consumed in air drying heating for $40,50,60$ and $70{ }^{\circ} \mathrm{C}$ air drying temperature,respectively. The total heat energy provided and consumed varied from one treatment to another due to the variation in the distribution of solar energy available and energy required in drying process. The main parameters affecting proportions of heat energy consumed in the form of electrical and solar energy were; solar collector surface area,ambient air temperature, solar energy available and drying air temperature required for drying process. 


\section{Matouk, A. M. et al.}

T.6 


\section{Conclusions}

1- Both of the examined models could satisfactorily describe the change in date moisture content during the drying process. While the, Page's model could predict the change in moisture content of date more adequately than the simple model.

2- Drying constants $\left(k_{s}\right.$ and $k_{p}$ ) increased with the increase of drying air temperature and air velocity. While the constant $(\mathrm{u})$ increased with the drying air temperature and decreased with air velocity.

3- The solar collector could provided 10.87 to $35.03 \%$ of total the required energy by energy consumed. The overall thermal efficiency of the solar dryer ranged from $19.19 \%$ to $53.53 \%$.

4- Total and reducing sugars percentages decreased with the decrease of drying air temperature and air velocity and it ranged from 40.33 to $44.66 \%$ d.b. for the reducing sugar and from 49.65 to $56.93 \%$ d.b. for the total soluable sugar.

\section{REFERENCES}

AOAC (1990)."Official methods of analysis of the association of official analytical chemists", Arlington, Virginia.

Abdellatif, S. M. (1989) "A comparative study of the thermal performance of solar panels with different diameters of copper pipe" Misr J. Agric. Eng., $6(1): 69-77$.

Azzouz, S.; A. Guizani; W. Jomaa and A. Belghith (2002). "Moisture diffusivity and drying kinetic equation of convective drying of grapes". Journal of Food Engineering 55: 323-330.

Bala, B. K.,( 1997a). "Drying and Storage of cereal grains", Oxford \& IBH Publishing Co.Pvt. Ltd, India,.

Bala, B. K., (1998)" Solar Drying Systems" . Simulation and Optimization, Agrotech Publishing Academy, India.

El-Sahrigi,A.F; A.M.Matouk, S.M.Abd El-Latief and A.SH.Awad.(2006). Modeling of thin layer drying of grapes under controlled conditions. Egypt J. Agric.Res.,84(6):1907-1923.

Excell, R. H. B. and Kornsakoo, S., (1978) "A low cost solar rice dryer", Appropriate Technology,5(1), 23-24.

Inayatullah ; Saifullah - khan ; Imam - Bakhsh ; Ahmed - kan Baloch.(1989).Suitability of dhakki dates for dehydration and storage. Sarhad J.Agric., 5:6 , 603-606

Kamal. M.A. (1968). "Agricultural Biochemistry. Faculty of Agriculture" ,Ain Shams University, Egypt. Published by Dar Al-Nahda Al-Arabia pp.204, 325- 326.

Matouk, A. M., Abd El-Latif, S. M., El-Hadidi, Y. M. and Tharwat, A., (2002) "Drying of ear corn: Part II: A mathematical model for thin layer drying". The 10th Annual Conference of the Misr. Society of Agric. Eng.16 - 17 October.

Oosthuizen, P. H., (1995) "The Design of Indirect Solar Rice Dryers", Journal of Engineering for International Development, 2(1): 20-27. 


\section{Matouk, A. M. et al.}

Mühlbauer, W. (1986). "Present status of solar crop drying", Energy in Agriculture, 5: 121-137.

Mohamed, M. A. and A. A. Ahmed. (1981). "Libyan date syrup (Rub AlTamar)". J. Food Sci., 46: 162-166.

Pangavhane, D.R.; R.L. Sawhney and P.N. Sarsavadia (1999)."Effect of various dipping pretreatment on drying kinetics of Thompson seedless grapes". J. of Food Engineering, 39: 211-216.

Somogi.M. (1952). Notes on sugar determination J.Biol. Chem., 195.19.

Sharma, V. K, Colangelo, A. and Spagna, G., (1995) "Experimental Investigation of different Solar Driers Suitable for Fruits and Vegetable Drying", Renewable Energy, 6(4): 413-424.

Reynolds,T.M.(1965). "Chemistry of non-enzymatic browning". Advances in Food Research, 14,299.

Zaman, M.A. and Bala, B.K.,( 1989) "Thin layer solar drying of rough rice", Solar Energy, 42: 167-171.

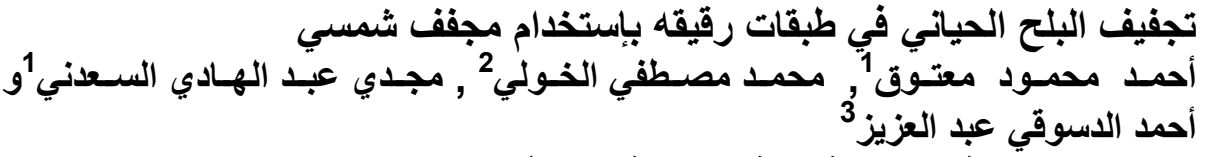

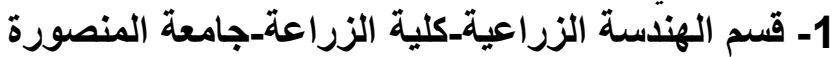

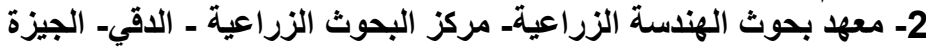

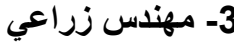

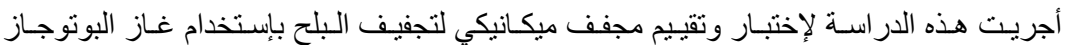

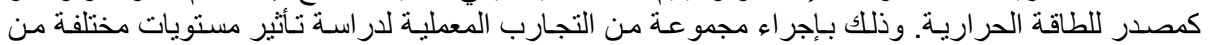

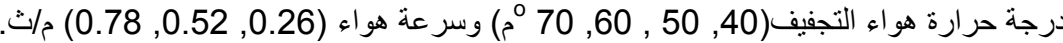

$$
\begin{aligned}
& \text { تم أيضا إختبار نموذجين رياضيين لوصف منحني التجفيف للبلح في طبقات رقيقه شملت ( الدعادلة البسيطة , } \\
& \text { معادلة Page) } \\
& \text { وقد أظهرت النتائج المتحصل عليها مايلي: } \\
& \text { 1. وصف كلا النموذجين الرياضيين التغير في المحتوي الرطوبي للبلح بشكل مرضي, بينما أعطت , معادلة }
\end{aligned}
$$

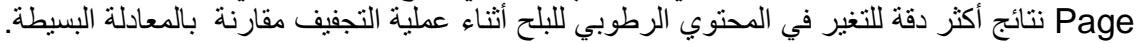

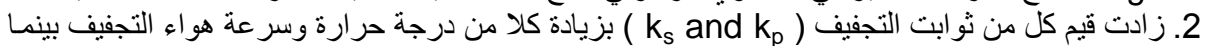

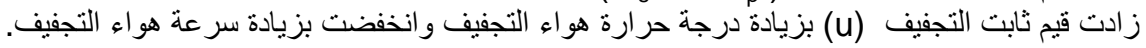

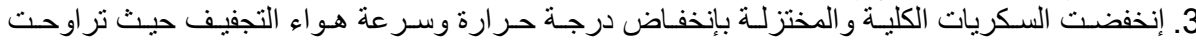

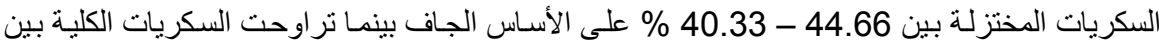

$$
\begin{aligned}
& 49.65 \text { - } 56.93 \text { \% على الأساس الجاف. }
\end{aligned}
$$

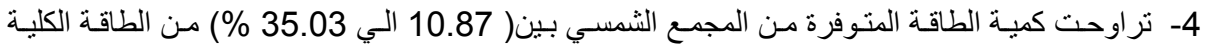

$$
\begin{aligned}
& \text { المستهلكة , بينما تراوحت الكفاءة الكلية للمجف الثمسي بين (19.19 الي } 53.53 \text { \%). }
\end{aligned}
$$





\section{J. Soil Sci. and Agric.Engineering,Mansoura Univ., Vol.1(6): , 2010}

Table (6): Thermal efficiency of the solar dryer at different drying air temperature and velocity.

\begin{tabular}{|c|c|c|c|c|c|c|c|c|c|c|c|c|c|c|c|c|}
\hline 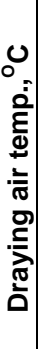 & 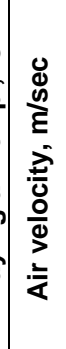 & 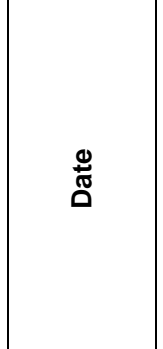 & 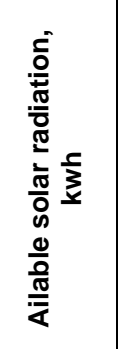 & $\begin{array}{l}0 \\
0 \\
1 \bar{\pi}\end{array}$ & $\begin{array}{l}0 \\
0 \\
0 \\
10\end{array}$ & 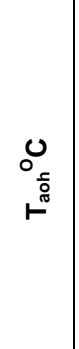 & 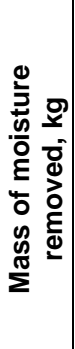 & 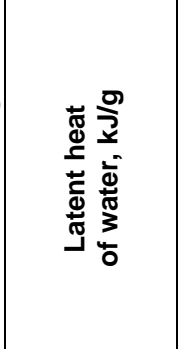 & 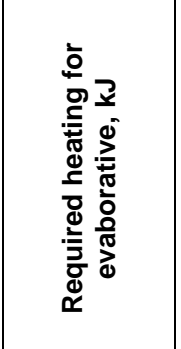 & 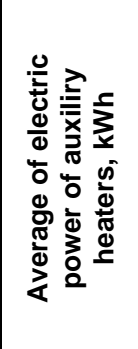 & 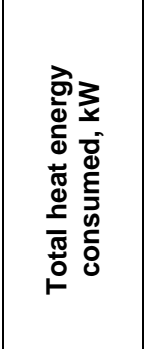 & 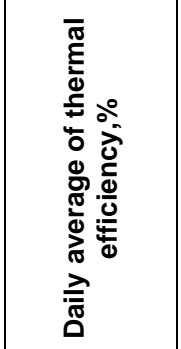 & 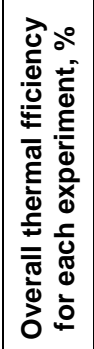 & 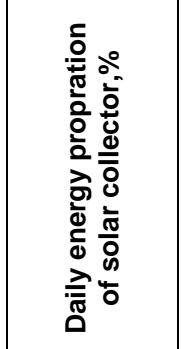 & 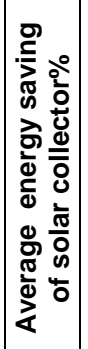 & 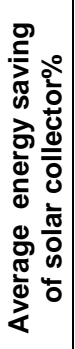 \\
\hline & & 10/2007 & \begin{tabular}{|l|}
1.0868 \\
\end{tabular} & 26.36 & 36.33 & 38.51 & 2.47 & 2536 & 663 & & 3.0968 & 3.53258617 & & 5.09429088 & & \multirow{9}{*}{31.03} \\
\hline \multirow{7}{*}{4} & & $25 / 10 / 2007$ & 1.055875 & 25.31 & 37.74 & \begin{tabular}{|l|}
39 \\
\end{tabular} & 0.805 & 2416.222536 & 1945.0 & 1.9875 & 3.043375 & & 29.29 & 34.69421284 & 35.03 & \\
\hline & & \begin{tabular}{|l|}
$26 / 10 / 2007$ \\
\end{tabular} & 1.085325 & 24.88 & 38.35 & 39.5 & 0.76 & 2416.222536 & 1836.3 & 1.9875 & 3.072825 & 16.600 & & 35.32010446 & & \\
\hline & & $29 / 10 / 2$ & 0.92945 & 25.3 & \begin{tabular}{|l|}
36.4 \\
\end{tabular} & 39.35 & 2.58 & 2415.26 & 6242.6 & 2.153 & 3.0827 & 56.25 & & 30. & & \\
\hline & & $30 / 10 / 2007$ & 0.883825 & 25.84 & 35.79 & 39 & 1.12 & 2415.266659 & 2719.89173 & 2.15325 & 3.037075 & 24.8767 & 33.60 & 29.10119111 & & \\
\hline & & $\mid 31 / 10 / 2007$ & & 25.73 & 38.08 & \begin{tabular}{|l|}
39.4 \\
\end{tabular} & \begin{tabular}{|l|}
0.89 \\
\end{tabular} & 2415.266659 & 2165.846373 & 2.15325 & 3.054725 & 19.6948659 & & 29.51083976 & & \\
\hline & $05 / 11 / 2007$ & 1.035477 & 27.06 & 38.91 & 40.01 & 2.77 & 2416.092267 & 6713.436421 & 2.303 & 3.338477 & 55.8591 & \multirow{3}{*}{34.04} & 31.01644852 & \multirow{3}{*}{28.48} & \\
\hline & & $\mid 06 / 11 / 2007$ & 0.900 & 25.73 & 36.68 & 39.05 & \begin{tabular}{|l|}
1.35 \\
\end{tabular} & 2416.0 & 3276 & 2.303 & 3.203531 & 28.409 & & 28.11057549 & & \\
\hline & & $\mid 07 / 11 / 2007$ & 0.8235 & 26.03 & 33.81 & 40.3 & 0.83 & 2416.092267 & 2010.94 & 2.303 & & 17.866 & & 26.33935711 & & \\
\hline \multirow{6}{*}{50} & 0.26 & $21 / 09 / 2007$ & 1.350459 & 28.36 & 40.68 & 48.76 & 3.08 & 2391.407845 & 7377.286911 & 3.078 & 4.428459 & 46.27447977 & \multirow{2}{*}{34.77} & 30.49500966 & \multirow{2}{*}{30.27} & \multirow{6}{*}{28.8} \\
\hline & & $22 / 09 / 2007$ & $\begin{array}{l}1.323 \\
\end{array}$ & 27.31 & 39.31 & 49.67 & 1.54 & 2391.4 & 3688.9 & 3.078 & 4.401 & 23.283 & & 30.061 & & \\
\hline & 52 & $25 / 09 / 2007$ & 1.3095 & 26.88 & 38.1 & 47.65 & 2.82 & 2391.318133 & 6758.448902 & 3.22575 & 4.53525 & 41.39456297 & \multirow{2}{*}{30.80} & 28.87382173 & \multirow{2}{*}{28.76} & \\
\hline & & $26 / 09 / 2007$ & 1.296 & 26.5 & 36.47 & 48.67 & \begin{tabular}{|l|}
1.37 \\
\end{tabular} & 2391.318133 & 3291.065553 & 3.22575 & 4.52175 & 20.217 & & 28.66146956 & & \\
\hline & 0.78 & $329 / 09 / 2007$ & 1.269 & 26 & 38.43 & 47.5 & \begin{tabular}{|l|}
3.78 \\
\end{tabular} & 5.387414 & & 3.3495 & & 54.553 & \multirow{2}{*}{36.87} & 27.47645339 & \multirow{2}{*}{27.37} & \\
\hline & & $30 / 0$ & 1.255986 & 25.34 & 38.81 & \begin{tabular}{|l|}
49.3 \\
\end{tabular} & 1.32 & 7414 & & 3.3495 & & 19.1 & & 27.271 & & \\
\hline \multirow{2}{*}{ c } & 0.26 & $03 / 10 / 2007$ & 1.140375 & 29.08 & 40.18 & 57.62 & 2.77 & 2368.888968 & 6568.422471 & 3.676725 & 4.8171 & 37.87676813 & \multirow{2}{*}{29.64} & 23.67347574 & \multirow{2}{*}{22.91} & \\
\hline & & $\mid 04 / 10 / 2007$ & 1.046775 & 28.16 & 38.11 & 58.9 & \begin{tabular}{|l|}
1.53 \\
\end{tabular} & 2368.888968 & 3641.488981 & 3.676725 & 4.7235 & 21.41472885 & & 22.16100349 & & \\
\hline & & $07 / 10 / 2007$ & 0.9385 & 27.17 & 39.52 & 57.71 & 3.02 & 2367.179558 & 7151.519426 & 3.7376625 & 4.6761625 & 42.48212447 & \multirow{2}{*}{33.262} & 20.06987567 & \multirow{2}{*}{20.51} & \multirow[b]{2}{*}{21} \\
\hline & & $08 / 10 / 2007$ & 0.99065 & 27.11 & 38.96 & 59.6 & 1.72 & 2367.179558 & 4092.583475 & 3.7376625 & 4.7283125 & 24.04301203 & & 20.95144938 & & \\
\hline & 0.78 & $11 / 10 / 2007$ & 0.8302 & 26.03 & 36.98 & 57.91 & 3.21 & 2371.824441 & 7615.085149 & 3.7674 & 4.5976 & 46.0088183 & \multirow[t]{2}{*}{-3638} & 18.05724726 & \multirow{2}{*}{19.58} & \\
\hline & & \begin{tabular}{|l|}
$12 / 10 / 2007$ \\
\end{tabular} & 1.008 & 27.06 & 34.84 & 58.38 & 1.93 & & & 3.7674 & & & & & & \\
\hline & 0.26 & $15 / 10 / 2007$ & 1.12165 & 26.66 & 38.98 & 67.65 & 4.41 & 2348.418213 & & 8.4 & 9.52165 & 30.21338015 & \multirow{2}{*}{\begin{tabular}{|l|}
30.21 \\
33.21 \\
\end{tabular}} & 11.77999611 & 11.78 & \\
\hline & .52 & $16 / 10 / 2007$ & 1.06285 & \begin{tabular}{|l|}
25.7 \\
\end{tabular} & 37.7 & 67.71 & 4.98 & 2347.068178 & 11688.39953 & 8.712 & 9.77485 & 33.21562629 & & 10.87331263 & 10.87 & $11.1 \mathrm{~s}$ \\
\hline & & $317 / 10 / 2007$ & & 26.1 & 37.32 & 67.88 & 5.33 & 2357.37548 & 12564.81131 & 8.928 & 10.022775 & 34.82294438 & 34.82 & 10.92287316 & 10.92 & \\
\hline
\end{tabular}

